\title{
Alkali feldspar crystallization kinetics in phonolites and peralkaline rhyolites
}

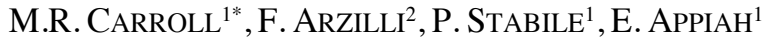 \\ ${ }^{1}$ Geology, Camerino University, 62032 Camerino, Italy \\ (*correspondence: michael.carroll@unicam.it, \\ paola.stabile@unicam.it,ernestina.appiah@unicam.it) \\ ${ }^{2}$ Dept. Earth and Environmental Sciences, University of \\ Manchester, Manchester M139PL, UK \\ (fabio.arzilli@manchester.ac.uk)
}

Alkali feldspar is frequently a dominant crystalline phase in evolved, alkali-rich magmas such as phonolites, trachytes, and alkaline rhyolites (e.g., pantellerites, commendites). In hydrous phonolites and trachytes, our previous studies [1,2] have shown that even small amounts of decompression $(<50$ $\mathrm{MPa}$ ) can produce large increases in amounts of Afsp on short timescales (several hrs to tens of hrs), with consequent large changes in magma viscosity and potentially changing eruptive dynamics to favor more explosive activity. We have completed more recent experiments involving both decompression and cooling of peralkaline rhyolitic melts (pantelleritic; molar $(\mathrm{Na}+\mathrm{K}) / \mathrm{Al} 1.4$ ) at both $\mathrm{H}_{2} \mathrm{O}$-saturated and undersaturated conditions and $680-800^{\circ} \mathrm{C}, 150-25 \mathrm{MPa}$ total pressure. Unlike previous results for trachy-phonolitic melts under similar conditions, the pantelleritic melts can exhibit significant delays (up to several days) in nucleation of Afsp, depending on the amount of undercooling and melt $\mathrm{H}_{2} \mathrm{O}$ content. This difference in Afsp nucleation rate between trachy-phonolitic and pantelleritic melts may explain the common lack of groundmass Afsp microlites in explosive pantelleritic eruptions and could serve to favor effusive over explosive eruption of pantelleritic magmas if ascent is not rapid [3].

[1] Arzilli \& Carroll (2013) ContMinPet 166, 1011-1027. [2] Arzilli et al. (2016) BullVolc 78, 72. [3] Hughes et al. (2017), JVGR 336, 179-191. 